\title{
Complexation Behavior in Aqueous Edta Sol-Gel Systems for the Synthesis of $\mathrm{YBa}_{2} \mathrm{Cu}_{3} \mathrm{O}_{7-\mathrm{x}}$ High-Temperature Superconductors
}

\author{
Tran Thi Thuy, ${ }^{*, a, b}$ Gerrit Herman, ${ }^{b}$ Petra Lommens ${ }^{b}$ and Isabel Van Driessche ${ }^{b}$ \\ ${ }^{a}$ Department of Analytical Chemistry, Hanoi University of Science and Technology, Dai Co Viet, Hanoi, Vietnam \\ ${ }^{b}$ Department of Inorganic and Physical Chemistry, Ghent University, Krijgslaan 281 - S3, 9000 Gent, Belgium
}

\begin{abstract}
Duas soluções à base de água contendo precursores do óxido $\mathrm{YBa}_{2} \mathrm{Cu}_{3} \mathrm{O}_{7-\mathrm{x}}$ e utilizando edta (ácido etilenodiaminotetra-acético) como agente complexante são apresentadas. Estes precursores foram usados na deposição de camadas finas de materiais supercondutores de altas temperaturas (HTSC). A influência do comportamento da complexação na formação de soluções e de géis transparentes e homogêneos após a combinação de acetatos de metais e outros modificadores foi estudada, comparada e interpretada utilizando equilíbrios metal-ligante. A ocorrência de diferentes espécies químicas em diferentes valores de $\mathrm{pH}$ pode estar relacionada às condições de formação de géis estáveis. Os precursores foram utilizados na deposição de filmes finos supercondutores texturizados por dip coating. A análise por difratometria de raios $\mathrm{X}$ de pó (XRD) indicou que uma única fase YBCO (óxido de ítrio, bário e cobre) foi obtida. A técnica de espectroscopia no infravermelho por refletância total atenuada (ATR-FTIR) foi utilizada para determinar o nível de carbono residual nos materiais YBCO finais, que foi menor do que $0,01 \%$.
\end{abstract}

Two water-based $\mathrm{YBa}_{2} \mathrm{Cu}_{3} \mathrm{O}_{7-\mathrm{x}}$ precursor solutions using edta (ethylenediaminetetraacetic acid) as complexing agent are presented. These precursors were employed to deposit thin layers of high-temperature superconducting (HTSC) materials. The influence of the complexation behavior on the formation of transparent and homogeneous solutions and gels after the combination of metal acetates and other modifiers was studied, compared and interpreted using metal-ligand equilibria. The occurrence of different chemical species at different $\mathrm{pH}$ values appears to be related to stable gel formation conditions. It is found that both acetic acid and edta play an important role in controlling the condensation reaction to form a continuous network polymer. The precursors were used to deposit textured superconducting thin films on $\mathrm{SrTiO}_{3}$ (STO) substrates by dip coating. Analysis by X-ray diffractometry (XRD) indicated that a single YBCO (yttrium barium copper oxide) phase was obtained. Attenuated total reflectance Fourier transform infrared spectroscopy (ATR-FTIR) was used to determine the carbon residue level in the YBCO final materials, which was lower than $0.01 \%$.

Keywords: solution speciation, superconductor, $\mathrm{YBa}_{2} \mathrm{Cu}_{3} \mathrm{O}_{7-\mathrm{x}}$, water-based sol-gel, edta

\section{Introduction}

Since 1987 enormous progress in research and development of YBCO (yttrium barium copper oxide) materials has been made, from known sintered polycrystalline bulk material (the first generation of high-temperature superconductors, HTSC) and thin films on small single crystal substrates, to thin films on a flexible inexpensive substrate with low cost film-making method for commercial applications (the second generation HTSC). The unique combination of YBCO thin layers on a flexible

*e-mail: thuytt-fct@mail.hut.edu.vn substrate opens the possibility of making large scale cables by the so-called coated conductor design. ${ }^{1}$

The use of water-based bulk materials and chemical solution deposition for the low-cost and environmentally friendly production of coated conductors has been previously published by our group and others. Besides the study of deposition parameters, heating procedures and measurements of the superconducting properties, our group constantly seeks to improve the stability of these water-based precursor solutions. A simple sol-gel synthesis technique was refined to prepare the precursors for superconducting $\mathrm{RE}_{1} \mathrm{Ba}_{2} \mathrm{Cu}_{3} \mathrm{O}_{y},\left(\mathrm{Y}_{1-x} \mathrm{Sc}_{x}\right) \mathrm{Ba}_{2} \mathrm{Cu}_{4} \mathrm{O}_{8}$ and $\left(\mathrm{Y}_{1-x} \mathrm{Ga}_{x}\right) \mathrm{Ba}_{2} \mathrm{Cu}_{4} \mathrm{O}_{8}$ compounds. ${ }^{1-3}$ The precursor gels 
were characterized by powder X-ray diffractometry (XRD), infrared spectroscopy, thermal analysis and elemental analysis. Some predictions of the approximate composition and the chemical reactions involved during gelation can be found. ${ }^{1}$ Promising results using non-fluorine YBCO precursor solutions in a polymer-assisted deposition method (PAD) or by using trimethylacetates as metal salts were also published. ${ }^{4-7}$ In the sol-gel systems that were previously published by our group, a highly viscous network is formed, e.g., by the addition of concentrated liquid amines to avoid the precipitation of the metal ions. Even at high concentrations, these metal ions remain captured in the so-called microcavities and the homogeneity is presented in a non-classical gel state. ${ }^{8-14}$

The introduction of a suitable ligand and an adjustment of the $\mathrm{pH}$ level are necessary to obtain a stable system and to avoid precipitation. A strong ligand such as edta is of preferable use in the synthesis of HTSC oxides. The sol-gel chemistry routes using edta as a complexing agent were previously successfully used to synthesize bulk HTSC oxides such as YBCO powders, ${ }^{15,16}$ ( $\mathrm{Hg}, \mathrm{Pb}) \mathrm{Ba}_{2} \mathrm{Ca}_{2} \mathrm{Cu}_{3} \mathrm{O}_{8+\delta},{ }^{17} \mathrm{Bi}-2223,{ }^{18} \mathrm{Y}_{2} \mathrm{O}_{3}$ : Eu nanopowder, ${ }^{19}$ (Ba,Sr) $(\mathrm{Zn}, \mathrm{Fe}) \mathrm{O}_{3-\delta}{ }^{20}$ and $\mathrm{Bi}_{2} \mathrm{Sr}_{2} \mathrm{Ca}_{2} \mathrm{Cu}_{3} \mathrm{Ox}$ (2223). ${ }^{21}$ The same sol-gel process was also applied for the deposition of thin films of $\mathrm{CeO}_{2}$ on Ni-W by our group, ${ }^{22,23}$ or YBCO coating on YSZ by powder melting growth process. ${ }^{24} \mathrm{It}$ was described in detail that an YBCO precursor solution can be obtained by dissolving stoichiometric amounts of Y, $\mathrm{Ba}$ and $\mathrm{Cu}$-acetates in acetic acid and adding chelating edta with the molar ratio of metal ions:ligand of $1: 1 .^{25} \mathrm{The} \mathrm{pH}$ value of the solution was adjusted with ammonia to $\mathrm{pH} 8$. However, during the evaporation, some sols segregated to microcrystals and became turbid, while others remained stable and transparent. ${ }^{25}$

In the research described here, the insights into the solution chemistry and the optimization of stable and wettable solutions are described by the combination of the following ligands: edta, ethylenediamine (eda), acetic acid and ammonia, which were selected based on the hyperquad simulation and speciation (HySS) program. This study leads to the possibility of working in completely aqueous media and with a minimum in organic content, thus giving environmentally benign and stable precursors for coated conductors.

\section{Experimental}

\section{Chemicals}

$\mathrm{Y}(\mathrm{OAc})_{3} \cdot 4 \mathrm{H}_{2} \mathrm{O}, \mathrm{Ba}(\mathrm{OAc})_{2}, \mathrm{Cu}(\mathrm{OAc})_{2} \cdot 0.98 \mathrm{H}_{2} \mathrm{O}, \mathrm{KNO}_{3}$, $\mathrm{HNO}_{3}$, eda and $\mathrm{H}_{4}$ edta were purchased from Sigma-Aldrich
(Germany). Ammonia (25 wt.\%) and glacial acetic acid (99 wt.\%) were obtained from Chem.-Lab (Belgium).

Thermogravimetric and differential thermal (TGA/DTA) analyses (TA Instruments STD 2960) were performed on the $\mathrm{Y}, \mathrm{Ba}$ and $\mathrm{Cu}$ acetates to determine the water content of the metal acetates and ensure an exact 1:2:3 stoichiometry of $\mathrm{Y}^{3+}, \mathrm{Ba}^{2+}$ and $\mathrm{Cu}^{2+}$ in the precursor solutions.

\section{HySS program}

The HySS program affords a system for simulating titration curves and providing speciation diagrams. ${ }^{26,27}$ It provides an integrated environment for setting up calculations and performing them, resulting in the distribution diagrams of the species present in solution. There are no limits imposed on the number of reagents, complexes or partially soluble products that may be present. Three types of measurements were performed using the program: (i) simulation of the titration curves, (ii) calculation of species concentrations for a range of conditions and (iii) speciation for a single set of conditions.

The results of the calculations lead to information on the types of equilibrium present in the solution and the presence of soluble and non-soluble species. The HySS program thereby supplies information on the influence of the type of complexing agents chosen, of the combination of complexing agents and of their ratio to the metal concentration necessary to obtain stable and clear solutions. It also helps in predicting the $\mathrm{pH}$ range in which the free concentration of the metal ions can be kept minimal to obtain a clear solution.

In our case, details about the initial concentrations and ratios of metal ions and ligands are added in the simulation. The simulations were performed for two water-based edta route precursor solutions and for a $\mathrm{pH}$ range from 1 to 11 . The stability constant data needed for that purpose were taken from the literature. ${ }^{28,29}$

\section{Preparation of solutions}

The scheme used to prepare the YBCO precursor solution 1 is indicated in Figure 1(a). This precursor was prepared by dissolving yttrium, barium and copper acetates in an acetic acid solution with a molar ratio $\mathrm{M}^{\mathrm{n}+}$ :acetic acid of 1.00:4.45 $\left(\mathrm{M}^{\mathrm{n}+}\right.$ is the total concentration of metal ions). The $\mathrm{pH}$ of precursor solution 1 was adjusted with ammonia to $\mathrm{pH}$ 6. Finally, an edta solution was added until a final molar ratio between edta and metal ions of 0.4:1.0 was reached. In the $\mathrm{pH}$ range 5.7-6.5, a homogeneous sol and gel could be obtained. 


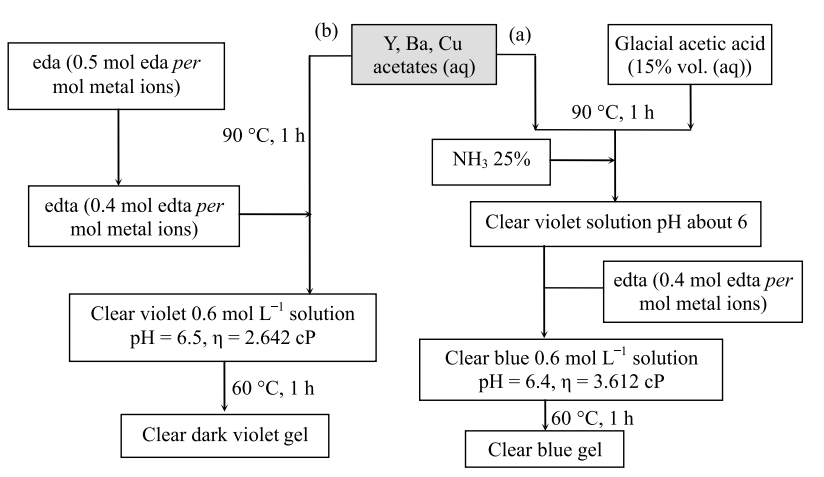

Figure 1. Schematic overview of the aqueous precursor solution 1 (a) and precursor solution 2 (b) using the edta route.

The scheme used to prepare the YBCO precursor solution 2 is shown in Figure 1(b). This precursor was prepared by dissolving yttrium, barium and copper acetates in a mixture of water, eda and edta with a molar ratio $\mathrm{M}^{\mathrm{n}+}$ :eda:edta of 1:0.5:0.4. This combination leads to clear, homogeneous sols and gels at a pH value between 6 and 7 . The pictures of both sols and gels of precursor solutions 1 and 2 are shown in Figure 2.

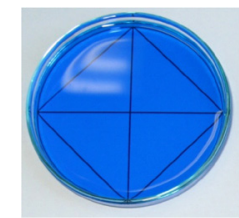

Sol 1

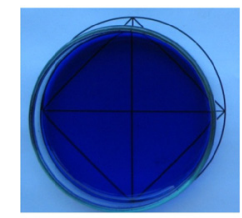

Sol 2

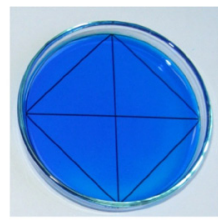

Gel 1

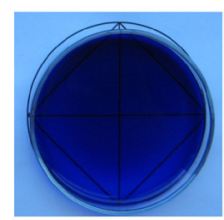

Gel 2
Figure 2. Clear and homogeneous sols and gels derived from precursor solutions 1 and 2 .

The shift of the $\lambda_{\max }$ value of copper complexes was studied by UV-Vis (Cary Varian 50 Conc) between 900 and $400 \mathrm{~nm}$. A pathlength of $0.1 \mathrm{~mm}$ was obtained by using two microscope slides separated by a polymer spacer of $0.10 \mathrm{~mm}$. This small pathlength allows UV-Vis measurement of the highly concentrated precursor solutions.

The thermal decomposition behavior of the gel was studied by TGA/DTA (TA Instruments SDT 2960). The identification of the different phases present in the YBCO films was performed by X-ray diffractometry (Siemens D5000, $\mathrm{Cu} \mathrm{K} \mathrm{K}_{\alpha}$. The critical temperature $\left(\mathrm{T}_{\mathrm{C}}\right)$ of the thin film was determined by resistivity measurements using a fourpoint test device (Keithley). Attenuated total reflectance with Fourier transform infrared spectroscopy (ATR-FTIR,
Perkin Elmer 160 FTIR) was used for analysis of the carbon residue in the YBCO materials.

\section{Results and Discussion}

As it is mentioned in a recent publication, the complexant in the YBCO system is chosen by focusing on $\mathrm{Y}^{3+}$ and $\mathrm{Cu}^{2+}$ in order to obtain homogeneous sols and gels. ${ }^{9}$ In the present study, edta, eda, acetic acid and ammonia were studied as candidate materials and two different sol-gel systems were prepared. The formulation of the YBCO precursors was first optimized by varying $\mathrm{pH}$ and molar ligand-to-metal ion-ratio. The organic content was kept as low as possible.

\section{Precursor solution 1}

The first YBCO precursor was prepared by dissolving $\mathrm{Y}$-, Ba- and $\mathrm{Cu}$-acetates in a mixture of acetic acid and water. This procedure was based on the work of Schoofs et al. ${ }^{11}$ In this work, metal acetates were dissolved in $25 \%$ vol. acetic acid. In our research, the concentration of acetic acid (in \% vol.) was decreased and varied from 12 to $25 \%$. After dissolving the precursor, the acidity of the solutions can be lowered by adding ammonia up to a $\mathrm{pH}$ value of 6 . Only the solutions containing at least $15 \%$ vol. of acetic acid are completely free of precipitates.

Although the main role of acetic acid is to decrease the hydrolysis rate thus making the precipitation of hydroxides more difficult, the ideal precursor solutions should contain a second stronger ligand to stabilize the acetic acid precursor solution during the gelation process. ${ }^{9}$ Therefore, edta was added in different molar ligand-to-metal ion-ratios (from 0.2 to 1.2) to improve the formation of a clear, transparent and stable gel. As known, edta in acid form is sparingly soluble in water. The neutralization of edta with weak bases like ammonia or eda to $\mathrm{pH} 6$ allows the preparation of an edta solution in a higher concentration range. ${ }^{30}$ The minimal amount of edta still leading to highly stable solutions and gels was reached at a molar ratio between edta and metal ions of 0.4 .

As mentioned above, edta, ammonia and acetic acid were chosen in this precursor solution 1 as complexing agents. With the ratio of $\mathrm{Y}^{3+}: \mathrm{Ba}^{2+}: \mathrm{Cu}^{2+}$ :acetic acid:ammonia:edta of 1.0:2.0:3.0:26.7:26.7:2.4, the distribution of different species was calculated using the HySS program with all stability constant data from literature (Table 1). ${ }^{28,29}$ The initial concentrations of $\mathrm{Y}^{3+}, \mathrm{Ba}^{2+}, \mathrm{Cu}^{2+}$, acetic acid, ammonia and edta were $0.1 \mathrm{~mol} \mathrm{~L}^{-1}, 0.2 \mathrm{~mol} \mathrm{~L}^{-1}, 0.3 \mathrm{~mol} \mathrm{~L}^{-1}, 2.67 \mathrm{~mol} \mathrm{~L}^{-1}$, $2.67 \mathrm{~mol} \mathrm{~L}^{-1}$ and $0.24 \mathrm{~mol} \mathrm{~L}^{-1}$, respectively. The barium 
complex species are not shown in Figure 3 due to the low percentage in which they are present, but they were taken into account in the simulation program. As can be seen in Figure 3, the edta modified precursor solution does not form hydroxide precipitates, not even at very high $\mathrm{pH}$ values. Copper and yttrium start forming complexes with edta already in acid medium. Acetic acid tends to form 2:1 (ligand:metal) complexes with yttrium and copper from $\mathrm{pH} 3$ on. Free yttrium and copper concentrations drop to almost zero at pH 5.7 and 5.0, respectively. In alkaline medium, ammonia competes with edta for the complexation of the copper ions. As a result, the yttriumedta complexes become more favored in acid medium. In order to keep the changes in $\mathrm{pH}$ value during gelation as low as possible and to have the lowest free concentration of metal ions, the optimal $\mathrm{pH}$ range is expected to be between 5.7 and 6.5. In this $\mathrm{pH}$ range, clear and stable solutions and gels could be obtained.

The existence of the two $\mathrm{Cu}$-complexes at the value of the working $\mathrm{pH}$ was also supported by UV-Vis measurements. Data from UV-Vis spectroscopy in Figure 4 show that in acid media from $\mathrm{pH} 4$ to 6 there is no significant shift in

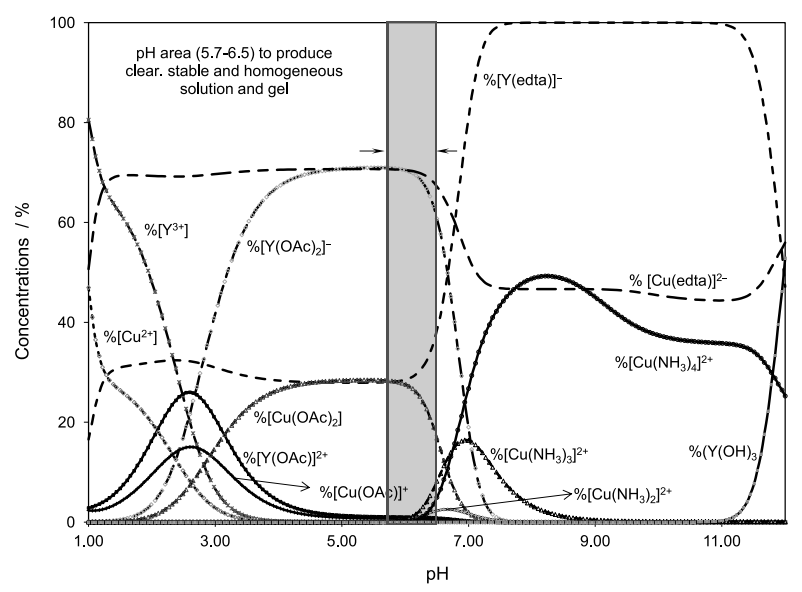

Figure 3. Distribution of species which contain $\mathrm{Y}^{3+}, \mathrm{Cu}^{2+}, \mathrm{NH}_{3}, \mathrm{HOAc}$ and edta at $25^{\circ} \mathrm{C}, \mu=0.1 \mathrm{~mol} \mathrm{~L}^{-1}$ (with the molar ratio $\mathrm{Y}^{3+}: \mathrm{Cu}^{2+}: \mathrm{NH}_{3}: \mathrm{HOAc}$ :edta $=1.0: 3 \cdot 0: 26.7: 6.7: 2.4)$.

$\lambda_{\max }$ due to the constant ratio between the two $\mathrm{Cu}$-complexes $[\mathrm{Cu}(\text { edta })]^{2-}$ and $\left[\mathrm{Cu}(\mathrm{OAc})_{2}\right]$, in agreement with the simulation in Figure 3. At higher $\mathrm{pH}, \lambda_{\max }$ shifts to shorter wavelengths. This is because copper is now complexing with ammonia. There is an isosbestic point at a wavelength of $630 \mathrm{~nm}$. Indeed, from $\mathrm{pH} 6.2 \mathrm{on},[\mathrm{Cu}(\mathrm{edta})]^{2-}$ and

Table 1. The stability constants and stoichiometric coefficients of complexes of $\mathrm{Y}^{3+}, \mathrm{Ba}^{2+}$ and $\mathrm{Cu}^{2+}$ with acetic acid, ammonia and edta $\left(25{ }^{\circ} \mathrm{C}, \mu=0.1\right)$ taken from the literature 28,29 and used for the complexation model with the HySS program

\begin{tabular}{|c|c|c|c|c|c|c|c|c|}
\hline Species & $\log \beta$ & $\mathrm{Y}^{3+}$ & $\mathrm{Ba}^{2+}$ & $\mathrm{Cu}^{2+}$ & $\mathrm{OAc}^{-}$ & $\mathrm{NH}_{3}$ & edta & $\mathrm{H}^{+}$ \\
\hline HOAc & 4.56 & 0 & 0 & 0 & 1 & 0 & 0 & 1 \\
\hline$[\mathrm{Y}(\mathrm{OAc})]^{2+}$ & 1.68 & 1 & 0 & 0 & 1 & 0 & 0 & 0 \\
\hline$\left[\mathrm{Y}(\mathrm{OAc})_{2}\right]^{+}$ & 3.17 & 1 & 0 & 0 & 2 & 0 & 0 & 0 \\
\hline$[\mathrm{Y}(\text { edta })]^{-}$ & 18.08 & 1 & 0 & 0 & 0 & 0 & 1 & 0 \\
\hline $\mathrm{Y}(\mathrm{OH})_{3}$ & -63.34 & 1 & 0 & 0 & 0 & 0 & 0 & -3 \\
\hline$[\mathrm{Cu}(\mathrm{OAc})]^{+}$ & 1.83 & 0 & 0 & 1 & 1 & 0 & 0 & 0 \\
\hline$\left[\mathrm{Cu}(\mathrm{OAc})_{2}\right]$ & 3.09 & 0 & 0 & 1 & 2 & 0 & 0 & 0 \\
\hline $\mathrm{Cu}(\mathrm{OH})_{2}$ & -46.88 & 0 & 0 & 1 & 0 & 0 & 0 & -2 \\
\hline $\mathrm{NH}_{4}^{+}$ & 9.32 & 0 & 0 & 0 & 0 & 1 & 0 & 1 \\
\hline$\left[\mathrm{Cu}^{2+}\left(\mathrm{NH}_{3}\right)\right]^{2+}$ & 4.24 & 0 & 0 & 1 & 0 & 1 & 0 & 0 \\
\hline$\left[\mathrm{Cu}^{2+}\left(\mathrm{NH}_{3}\right)_{2}\right]^{2+}$ & 7.83 & 0 & 0 & 1 & 0 & 2 & 0 & 0 \\
\hline$\left[\mathrm{Cu}^{2+}\left(\mathrm{NH}_{3}\right)_{3}\right]^{2+}$ & 10.80 & 0 & 0 & 1 & 0 & 3 & 0 & 0 \\
\hline$\left[\mathrm{Cu}^{2+}\left(\mathrm{NH}_{3}\right)_{4}\right]^{2+}$ & 13.00 & 0 & 0 & 1 & 0 & 4 & 0 & 0 \\
\hline$\left[\mathrm{Cu}^{2+}\left(\mathrm{NH}_{3}\right)_{5}\right]^{2+}$ & 12.43 & 0 & 0 & 1 & 0 & 5 & 0 & 0 \\
\hline Hedta $^{3-}$ & 10.17 & 0 & 0 & 0 & 0 & 0 & 1 & 1 \\
\hline $\mathrm{H}_{2}$ edta $^{2-}$ & 16.28 & 0 & 0 & 0 & 0 & 0 & 1 & 2 \\
\hline $\mathrm{H}_{3} \mathrm{edta}^{-}$ & 18.96 & 0 & 0 & 0 & 0 & 0 & 1 & 3 \\
\hline $\mathrm{H}_{4}$ edta & 20.96 & 0 & 0 & 0 & 0 & 0 & 1 & 4 \\
\hline $\mathrm{H}_{5} \mathrm{edta}^{+}$ & 22.46 & 0 & 0 & 0 & 0 & 0 & 1 & 5 \\
\hline $\mathrm{H}_{6} \mathrm{edta}^{2+}$ & 22.46 & 0 & 0 & 0 & 0 & 0 & 1 & 6 \\
\hline$[\mathrm{Cu}(\text { edta })]^{2-}$ & 18.80 & 0 & 0 & 1 & 0 & 0 & 1 & 0 \\
\hline$\left[\mathrm{Cu}(\text { edta })_{2}\right]^{6-}$ & 21.80 & 0 & 0 & 1 & 0 & 0 & 2 & 0 \\
\hline$[\mathrm{Ba}(\mathrm{OAc})]^{+}$ & 0.39 & 0 & 1 & 0 & 1 & 0 & 0 & 0 \\
\hline$[\mathrm{Ba}(\text { edta })]^{2-}$ & 7.80 & 0 & 1 & 0 & 0 & 0 & 1 & 0 \\
\hline $\mathrm{Ba}(\mathrm{OH})_{2}$ & -29.86 & 0 & 1 & 0 & 0 & 0 & 0 & -2 \\
\hline $\mathrm{OH}^{-}$ & -13.78 & 0 & 0 & 0 & 0 & 0 & 0 & -1 \\
\hline
\end{tabular}

The compositions of the species are given with stoichiometric coefficients. A negative coefficient for $\mathrm{H}^{+}$means bonded $\mathrm{OH}^{-}$. 
$\left[\mathrm{Cu}\left(\mathrm{NH}_{3}\right)_{4}\right]^{2+}$ complexes govern the precursor solution leading to an equivalent molar absorption.

Although $\left[\mathrm{Cu}\left(\mathrm{NH}_{3}\right)_{2}\right]^{2+}$ and $\left[\mathrm{Cu}\left(\mathrm{NH}_{3}\right)_{3}\right]^{2+}$ are also detected from $\mathrm{pH} 6$ to 9 , their concentration is at most $16 \%$ (Figure 3), thus not influencing the absorption in UV-Vis measurements. Moreover, because the absorption capacity of $\left[\mathrm{Cu}\left(\mathrm{NH}_{3}\right)_{n}\right]^{2+}(\mathrm{n}=1-6)$ is much lower than copper(II)-edta, the influence of these complexes in the spectra will be negligible. It is noted that the yttrium(III)- and barium(II)-edta complexes do not absorb in the visible region of the spectra, although their presence is confirmed by the simulation.

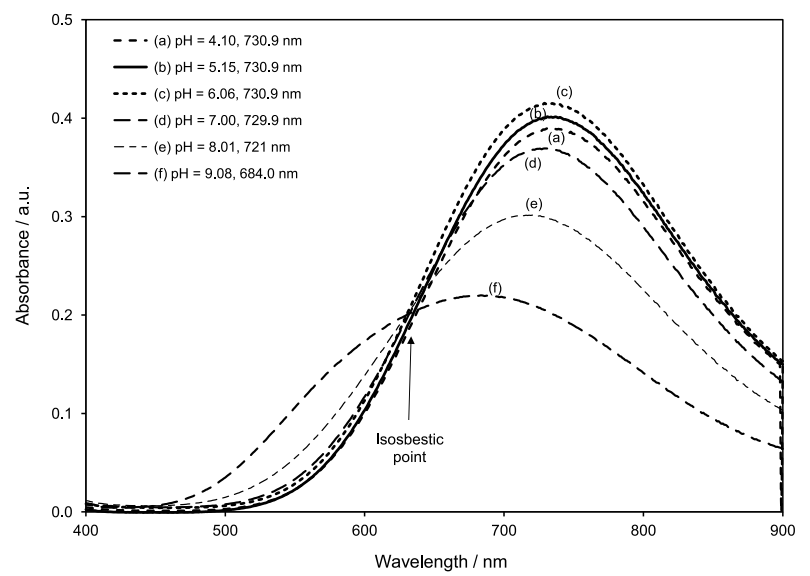

Figure 4. Absorption spectra of the precursor solution 1 between $\mathrm{pH} 4.10$ and 9.08 .

\section{Precursor solution 2}

YBCO precursor system 2 was prepared by dissolving $\mathrm{Y}-, \mathrm{Ba}-$ and $\mathrm{Cu}-$ acetates in water at temperatures of $60-90{ }^{\circ} \mathrm{C}$. Highly concentrated solutions of edta in eda were added, with different molar ratios, to the solution containing Y-, Ba- and $\mathrm{Cu}$-acetates, in order to screen for clear solutions and gels. The molar ratio between edta and metal ions was varied from 0.2 to 0.9 . The acidity of the obtained solutions was decreased by eda up to a $\mathrm{pH}$ value of 6.0 to 7.0. The minimal amount of edta still leading to highly stable solutions and gels was reached at a molar ratio between edta and metal ions of 0.4 .

Eda is appropriate as chelating agent because it binds to the metal ions through two nitrogen atoms. ${ }^{29} \mathrm{It}$ is the lowest molecular weight $\left(60.10 \mathrm{~g} \mathrm{~mol}^{-1}\right)$ member of the ethyleneamine family. Moreover, the neutralization of edta with eda results in the formation of edta salts with a significantly increased solubility in water. ${ }^{30}$

Both solutions and gels derived from this precursor are clear and homogeneous. However, a prolonged shelf life is seen for solution 2. Two important differences between ammonia (used in solution 1) and eda (used in solution 2) might explain this difference in stability for both solutions and gels. First, eda has a higher boiling point than $\mathrm{NH}_{3}\left(116^{\circ} \mathrm{C}\right.$ for eda and $36{ }^{\circ} \mathrm{C}$ for ammonium hydroxide $10-30 \% \mathrm{NH}_{3}$ ) and thus $\mathrm{NH}_{3}$ might evaporate much faster from the solution and from the gel causing important variations of $\mathrm{pH}$. Moreover, in contrast to ammonia, the two amine functional groups of eda can react with the carboxylic group of edta with the formation of a polyamide. ${ }^{31,32}$ This polyamide might further stabilize the yttrium(III), barium(II) and copper(II) ions forming a very stable continuous network in the gel.

For precursor solution 2, with a ratio of $\mathrm{Y}^{3+}: \mathrm{Cu}^{2+}$ :eda:edta of 1.0:3.0:3.0:2.4, the distribution of the different species was also calculated using the HySS program. The initial concentrations of $\mathrm{Y}^{3+}, \mathrm{Ba}^{2+}, \mathrm{Cu}^{2+}$, eda and edta were 0.1, $0.2,0.3,0.3$ and $0.24 \mathrm{~mol} \mathrm{~L}^{-1}$, respectively. The model is shown in Table 2 and the results in Figure 5. As seen for precursor solution 1, yttrium and copper immediately coordinate with edta in acidic media. At a $\mathrm{pH}$ value of 3.5 , eda starts to coordinate with $\mathrm{Cu}^{2+}$ to form $[\mathrm{Cu}(\text { eda })]^{2+}$. Free yttrium and copper concentrations drop almost to zero at $\mathrm{pH} 5.5$ and 6.0, respectively. The lowest $\mathrm{pH}$ value at which a clear solution can be obtained is 6.0. Yttrium hydroxide starts to precipitate at $\mathrm{pH}$ 7. In order to keep the lowest concentration of $\mathrm{Y}^{3+}$ and $\mathrm{Cu}^{2+}$ possible and to avoid precipitation of $\mathrm{Y}(\mathrm{OH})_{3}$, the optimal $\mathrm{pH}$ value of the precursor solution should be kept in the $\mathrm{pH}$ range 6-7. Under these $\mathrm{pH}$ conditions, the precursor solution produces clear, stable and homogeneous sols and gels.

\section{Comparative study between precursor systems 1 and 2}

It was observed that precursor solution 2 leads to more stable gels compared to solution 1. Moreover, the carbon and nitrogen contents in precursor 2 are much lower than in precursor 1 as shown in Table 3. This leads to reduced mass losses during thermal treatment and less intense thermal decompositions. It might thus be expected that system 2 will lead to a better morphology and structure in the final material. In precursor system 1, the presence of ammonia and acetic acid is considered a disadvantage during the heat treatment or when the gelation was performed at high temperature. Furthermore, eda in precursor 2 provides a higher stability of precursor solution than ammonia at higher temperature due to the huge difference between the boiling points of eda and ammonia. ${ }^{33}$

\section{Characterization of the gels}

The thermal decomposition behavior of YBCO precursor gels 1 and 2 was studied with TGA under air 
Table 2. The stability constants and stoichiometric coefficients of the complexes of $\mathrm{Y}^{3+}, \mathrm{Ba}^{2+}$ and $\mathrm{Cu}^{2+}$ with eda and edta $\left(25{ }^{\circ} \mathrm{C}\right.$, $\left.\mu=0.1\right)$ taken from the literature ${ }^{28,29}$ and used for the complexation model with the HySS program

\begin{tabular}{|c|c|c|c|c|c|c|c|}
\hline Species & $\log \beta$ & $\mathrm{Y}^{3+}$ & $\mathrm{Ba}^{2+}$ & $\mathrm{Cu}^{2+}$ & eda & edta & $\mathrm{H}^{+}$ \\
\hline$[\mathrm{Y}(\text { edta })]^{-}$ & 18.08 & 1 & 0 & 0 & 0 & 1 & 0 \\
\hline $\mathrm{Y}(\mathrm{OH})_{3}$ & -63.34 & 1 & 0 & 0 & 0 & 0 & -3 \\
\hline $\mathrm{Cu}(\mathrm{OH})_{2}$ & -46.88 & 0 & 0 & 1 & 0 & 0 & -2 \\
\hline Hedta $^{3-}$ & 10.17 & 0 & 0 & 0 & 0 & 1 & 1 \\
\hline $\mathrm{H}_{2} \mathrm{edta}^{2-}$ & 16.28 & 0 & 0 & 0 & 0 & 1 & 2 \\
\hline $\mathrm{H}_{3}$ edta $^{-}$ & 18.96 & 0 & 0 & 0 & 0 & 1 & 3 \\
\hline $\mathrm{H}_{4}$ edta & 20.96 & 0 & 0 & 0 & 0 & 1 & 4 \\
\hline $\mathrm{H}_{5} \mathrm{edta}^{+}$ & 22.46 & 0 & 0 & 0 & 0 & 1 & 5 \\
\hline $\mathrm{H}_{6} \mathrm{edta}^{2+}$ & 22.46 & 0 & 0 & 0 & 0 & 1 & 6 \\
\hline$[\mathrm{Cu}(\text { edta })]^{2-}$ & 18.80 & 0 & 0 & 1 & 0 & 1 & 0 \\
\hline$\left[\mathrm{Cu}(\text { eda })_{2}\right]^{6-}$ & 21.80 & 0 & 0 & 1 & 0 & 2 & 0 \\
\hline Heda & 9.89 & 0 & 0 & 0 & 1 & 0 & 1 \\
\hline $\mathrm{H}_{2} \mathrm{eda}$ & 16.97 & 0 & 0 & 0 & 1 & 0 & 2 \\
\hline$[\mathrm{Cu}(\text { eda })]^{2+}$ & 10.54 & 0 & 0 & 1 & 1 & 0 & 0 \\
\hline$\left[\mathrm{Cu}(\mathrm{eda})_{2}\right]^{2+}$ & 19.60 & 0 & 0 & 1 & 2 & 0 & 0 \\
\hline$[\mathrm{Ba}(\text { edta })]^{2-}$ & 7.80 & 0 & 1 & 0 & 0 & 0 & 0 \\
\hline $\mathrm{Ba}(\mathrm{OH})_{2}$ & -29.86 & 0 & 1 & 0 & 0 & 0 & -2 \\
\hline $\mathrm{OH}^{-}$ & -13.78 & 0 & 0 & 0 & 0 & 0 & -1 \\
\hline
\end{tabular}

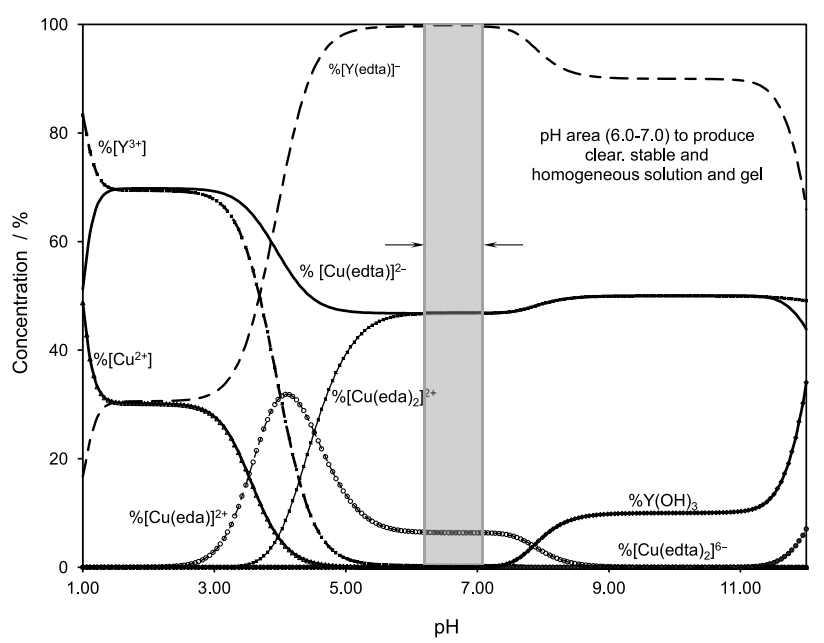

Figure 5. Distribution of species which contain $\mathrm{Y}^{3+}, \mathrm{Cu}^{2+}$, eda and edta at $25{ }^{\circ} \mathrm{C}, \mu=0.1 \mathrm{~mol} \mathrm{~L}^{-1}$ (with the molar ratio $\mathrm{Y}^{3+}: \mathrm{Cu}^{2+}$ :eda:edta $=$ $1.0: 3.0: 1.0: 2.4)$.

in order to obtain information on the heat treatment. The heating rate was $10^{\circ} \mathrm{C} \mathrm{min}^{-1}$. Figure 6 shows the TGA/DTA curves for gels 1 (curve a) and 2 (curve b) in the range from 25 to $1000{ }^{\circ} \mathrm{C}$. The sample weights of gel 1 and gel 2 were 14.8427 and $15.3220 \mathrm{mg}$, respectively.

A large decomposition step occurs at $174{ }^{\circ} \mathrm{C}$ in gel 1 . This step was associated with the release of water, acetic acid and ammonia. ${ }^{34}$ After this dehydration reaction, it was assumed that the metal complexes start decomposing to intermediate compounds such as $\mathrm{Cu}_{2} \mathrm{O}$ and $\mathrm{Y}_{2} \mathrm{O}_{2} \mathrm{CO}_{3}$ with release of $\mathrm{CO}_{x}$ and $\mathrm{NO}_{x} \cdot{ }^{35-37} \mathrm{In}$ gel 2 , eda undergoes a very fast degradation at temperatures between 174 and $375^{\circ} \mathrm{C}$. As it is inferred from the comparison between precursor
Table 3. Overview of precursor systems 1 and 2

\begin{tabular}{lcc}
\hline \multirow{2}{*}{$\begin{array}{l}\text { Starting } \\
\text { materials }\end{array}$} & \multicolumn{2}{c}{ Precursor system (molar content) } \\
\cline { 2 - 3 } & 1 & 2 \\
\hline Y-, Ba- and & $\begin{array}{c}\text { Y-, Ba- and } \\
\text { Cu-acetates }=1: 2: 3\end{array}$ & $\begin{array}{c}\text { Cu-acetates }=1: 2: 3 \\
\text { eda }\end{array}$ \\
$\mathrm{NH}_{3}$ & 0.4 & 2.4 \\
HOAc & 26.7 & 3.0 \\
Carbon & 26.7 & 0 \\
Nitrogen & $31.5(=2.4 \times 2+26.7 \times 1)$ & $10.8(=2.4 \times 2+3 \times 2)$ \\
\hline Sol & $\mathrm{h}$ & 0 \\
Gel & $\mathrm{h}$ & $\mathrm{h}$ \\
\hline
\end{tabular}

$\mathrm{h}$ : homogeneous.

systems 1 and 2, the concentration of metal ions in gel 2 is much higher than in gel 1 . Therefore, the intensity of the exothermic peak at $460{ }^{\circ} \mathrm{C}$ is higher for gel 2 than for gel 1. In gel 2, more links between metal ions and other atoms are formed and therefore more energy is released.

The decomposition of the metal complexes in the gel was complete at about $500{ }^{\circ} \mathrm{C}$, as seen in Figure 6. This was also indicated by FTIR measurements as shown in Figure 7. All peaks observed in the spectra (Figure 7) were assigned similarly in our previous publication. ${ }^{9}$ $\mathrm{CuO}$ may be formed at $550{ }^{\circ} \mathrm{C}$. For rare earth acetates such as yttrium acetate, there is no evidence for the presence of the normal carbonate in the TGA/DTA data. ${ }^{35}$ 


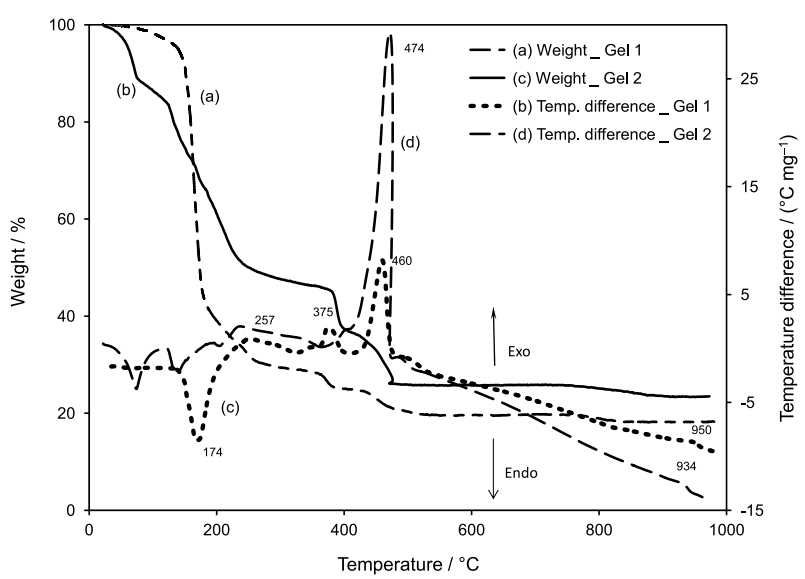

Figure 6. TGA/DTA curves for the decomposition of the $\mathrm{YBCO}$ precursor gels derived from precursors 1 and 2 with a heating rate of $10^{\circ} \mathrm{C} \mathrm{min}{ }^{-1}$.

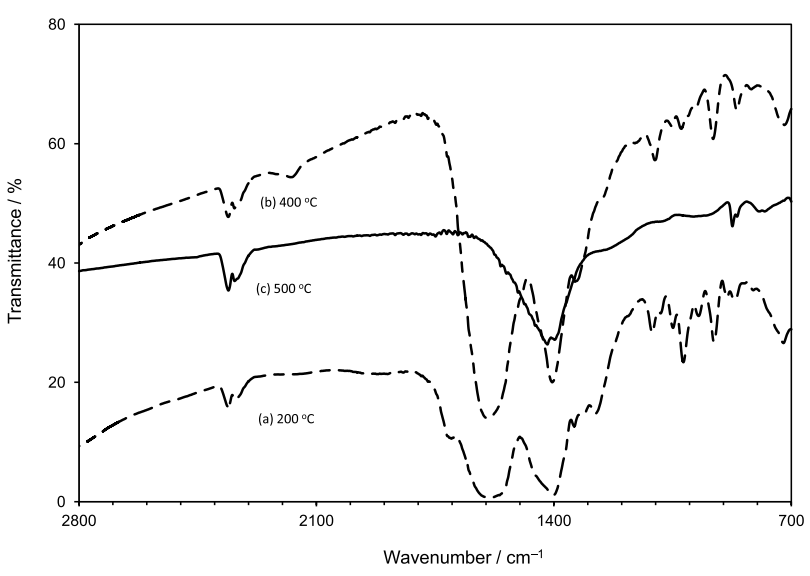

Figure 7. FTIR spectra of the YBCO gel and its heated samples derived from precursor 1 .

Barium acetate decomposes into barium carbonate and acetone at $455^{\circ} \mathrm{C}$ and decomposes further to oxide above $1000{ }^{\circ} \mathrm{C} .{ }^{38}$ Broad peaks located at 934 and $950{ }^{\circ} \mathrm{C}$ in curves a and $\mathrm{b}$, respectively, can be assigned to the combustion of residual carbon. ${ }^{39}$ Metal oxides convert to the desired $\mathrm{YBCO}$ phase at the sintering temperature above 930 to $950{ }^{\circ} \mathrm{C}$ in air. ${ }^{11}$

\section{Characterization of YBCO materials}

A heat treatment with a sintering temperature of $810^{\circ} \mathrm{C}$ in a low oxygen concentration for $2 \mathrm{~h}$ followed by annealing at $400{ }^{\circ} \mathrm{C}$ in pure oxygen for $5 \mathrm{~h}$ was applied to synthesize YBCO thin films on STO using precursor solution $2 .{ }^{8} \mathrm{XRD}$ patterns in Figure 8 indicate predominantly $(00 l)$ peaks. The $\mathrm{T}_{\mathrm{C}}$ measurement in liquid nitrogen shows an onset transition around $92 \mathrm{~K}$. The result is presented in Figure 9. These results show that these precursor systems are adequate for the synthesis of YBCO thin films. More intense research will be performed on the optimization of thermal treatment to obtain improved superconducting properties.

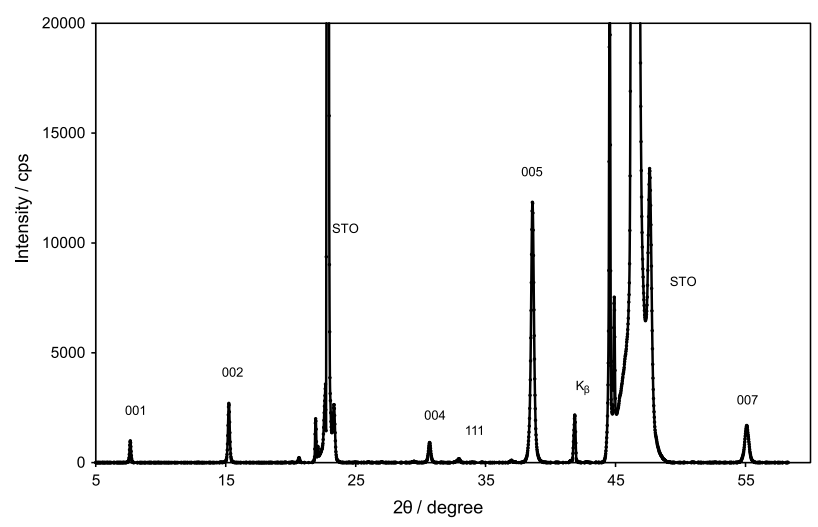

Figure 8. XRD pattern of the YBCO thin film coated on STO substrate.

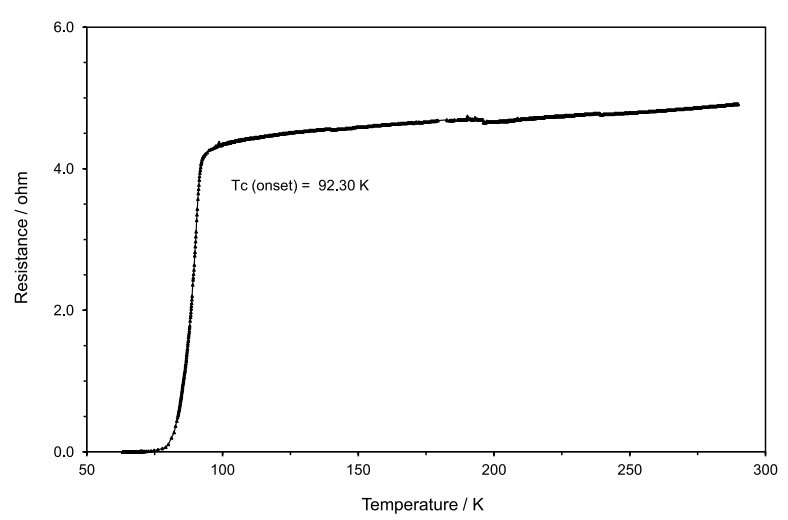

Figure 9. $\mathrm{T}_{\mathrm{C}}$ measurement for an $\mathrm{YBCO}$ thin film.

ATR-FTIR was used to verify the assumption of low carbon residues using water-based precursors. The IR high frequency region (2800-3000 $\left.\mathrm{cm}^{-1}\right)$ and low frequency region $\left(1600-1200 \mathrm{~cm}^{-1}\right)$ were examined. The reflection at $2800-3000 \mathrm{~cm}^{-1}$ is typical for $\mathrm{C}-\mathrm{H}$ stretching, showing the remainders of organic compounds from the precursor or contaminants from the environment. Since the samples have been treated at high temperatures, it is to be expected that no traces of these materials were left, which was also experimentally shown.

The analysis here mainly focused on the presence of $\mathrm{BaCO}_{3}$ and carbonates in general since these materials can be expected to form at high temperature as decomposition products of water-based precursors or as common contaminants of oxide surfaces. Since these carbonates are very stable at high temperatures, a study of their presence was undertaken to make sure that no traces were left. The data are displayed in Figure 10.

If the YBCO material contained carbonate residues, a peak due to a $\mathrm{C}=\mathrm{O}$ stretch in the region of $1400-1500 \mathrm{~cm}^{-1}$ was expected. The sensitivity of the used ATR-FTIR spectrometer was determined to be $0.01 \%$ as established for the detection of the $\mathrm{C}=\mathrm{O}$ stretch of sodium carbonate at $1420 \mathrm{~cm}^{-1}$, in a matrix of sodium chloride. ${ }^{40}$ However, when analyzing the YBCO bulk material and film surfaces, 


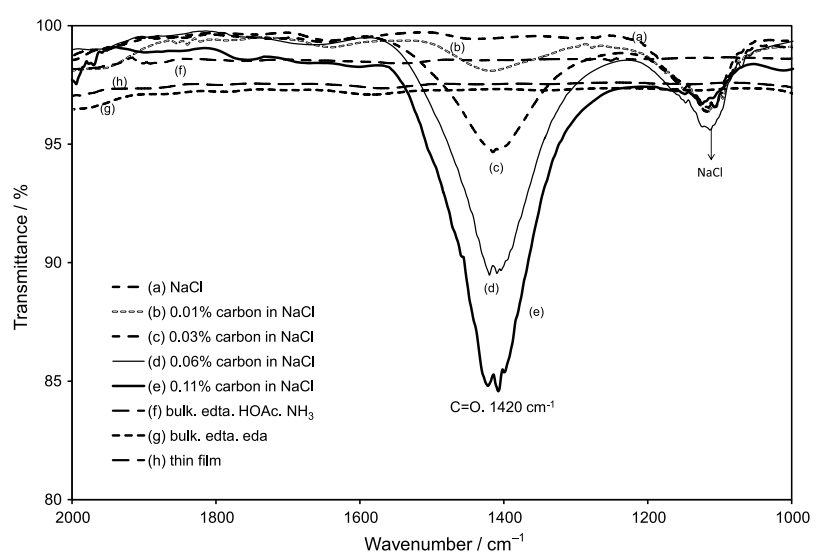

Figure 10. ATR-FTIR data to determine the amount of carbon residue in the surface of the YBCO bulk material and thin films (a) $\mathrm{NaCl}$, (b) $0.01 \%$ carbon in $\mathrm{NaCl}$, (c) $0.03 \%$ carbon in $\mathrm{NaCl}$, (d) $0.06 \%$ carbon in $\mathrm{NaCl}$, (e) $0.11 \%$ carbon in $\mathrm{NaCl}$, (f) bulk material derived from precursor 1 , (g) bulk material derived from precursor 2 and (h) YBCO thin film derived from precursor 2 .

no evidence for a $\mathrm{C}=\mathrm{O}$ stretch could be detected in this region. Hence, the level of carbon residue in the YBCO films is assumed to be lower than $0.01 \%$.

\section{Conclusion}

The behavior of the metal ion complexation in two water-based precursor systems for the synthesis of superconducting YBCO materials was examined. The formation of transparent and homogenous sols and gels by the combination of $\mathrm{Y}, \mathrm{Ba}$ and $\mathrm{Cu}$ acetates, edta, acetic acid and ammonia and the combination of metal acetates, edta and eda was studied, interpreted and compared using simulated metal-ligand equilibria with the HySS program. The second precursor system not only leads to more stable gels but also has a simple formulation displaying a long-term stability. The occurrence of different species at different $\mathrm{pH}$ values appears to be related to the conditions to form stable gels. It is found that both acetic acid and eda play an important role in controlling the condensation reaction to form a continuous network polymer. Sample thin film species were prepared with good superconducting behavior. The amount of carbon residue in the bulk materials and thin films is shown to be lower than $0.01 \%$.

\section{Acknowledgments}

The authors would like to acknowledge the help of O. Janssens (Ghent University) for the XRD measurements and J. Caroen (Ghent University) for ATR-FTIR measurements and discussion. Thuy T. T. would like to thank the Lotus Project - Lot 12 Asia Regional for funding to finalize the article.

\section{References}

1. Peleckis, G.; Tõnsuaadu, K.; Baubonyte, T.; Kareiva, A.; J. Non-Cryst. Solids 2002, 311, 250.

2. Donglu, S.; Yongli, X.; Haibo, Y.; Han, Z.; Lian, J.; Wang, L.; Li, A.; Liu, H. K.; Dou, S. X.; Supercond. Sci. Technol. 2004, 17,1420

3. Schoofs, B.; Van De Vyver, D.; Vermeir, P.; Schaubroeck, J.; Hoste, S.; Herman, G. G.; Van Driessche, I.; J. Mater. Chem. 2007, 17, 1714.

4. Manabe, T.; Sohma, M.; Yamaguchi, I.; Kondo, W.; Tkukada, K.; Mizuta, S.; Kumagai, T.; Phys. C 2004, 412-414, 896.

5. Patta, Y. R.; Wesolowski, D. E.; Cima, M. J.; Phys. C 2009, 469, 129.

6. Wesolowski, D. E.; Patta, Y. R.; Cima, M. J.; Phys. C 2009, 469, 766 .

7. Zhang, Y. L; Yao, X.; Lian, J.; Phys. C 2006, 436, 62.

8. Vermeir, P.; Cardinael, I.; Backer, M.; Schaubroeck, J.; Schacht, E.; Hoste, S.; Van Driessche, I.; Supercond. Sci. Technol. 2009, 22, 075009-5pp.

9. Thuy, T. T.; Hoste, S.; Herman, G. G.; Buysser, K. D.; Lommens, P.; Frey J.; Vandeput, D.; Van Driessche, I.; J. Sol-Gel Sci. Technol. 2009, 52, 124.

10. Van Driessche, I.; Penneman, G.; Bruneel, E.; Hoste, S.; Pure Appl. Chem. 2002, 74, 2101.

11. Schoofs, B.; Van de Vyver, D.; Vermeir, P.; Schaubroeck, J.; Hoste, S.; Herman, G.; Van Driessche, I.; J. Mater. Chem. 2007, 17,1714 .

12. Van Driessche, I.; Cattoir, S.; Hoste, S.; Appl. Supercond. 1994, $2,10$.

13. De Buysser, K.; Lommens, P.; De Meyer, C.; Bruneel, E.; Hoste, S.; Van Driessche, I.; Ceram. Silik. 2004, 48, 139.

14. Mouganie, I.; Moram, M. A.; Sumner, J.; Glowacki B. A.; Schoofs, B.; Van Driessche, I.; Hoste, S.; J. Sol-Gel Sci. Technol. 2005, 36, 87.

15. Brylewski, T.; Przybylski, K.; Appl. Supercond. 1993, 1, 737.

16 Motta, M.; Deimling, C. V.; Saeki, M. J.; Lisboa-Filho, P. N.; J. Sol-Gel Sci. Technol. 2008, 46, 201.

17. Przybylski, K.; Brylewski, T.; Morawski, A.; Lada, T.; J. Therm. Anal. Calorim. 2001, 65, 391.

18. Rouessac, V.; Wang, J.; Provost, J.; Desgardin, G.; J. Mater. Sci. 1996, 31, 3387.

19. Zhai, Y. Q.; Yao, Z. H.; Ding, S. W.; Qiu, M. D.; Zhai, J.; Mater. Lett. 2003, 57, 2901.

20. Feldhoff, A.; Martynczuk, J.; Wang H.; Prog. Solid State Chem. 2007, 35, 339.

21. Arshad, M.; Qureshi, A.; J. Therm. Anal. Calorim. 2006, 83, 415.

22. Thuy, T. T.; Narayanan, V.; Van de Velde, N.; De Buysser, K.; Lommens, P.; Herman, G. G.; Cloet, V.; Van Driessche, I.; J. Solid State Chem. 2010, 183, 2154. 
23. Van Driessche, I.; Penneman, G.; De Meyer, C.; Stambolova, I.; Bruneel, E.; Hoste, S.; Key Eng. Mater. 2002, 206-2, 479.

24. Zhao, Y. E.; He, Z. H; Luo, Y. Y; Gawalek, W.; Phys. C. 2004, 415, 197.

25. Zhao, Y. E.; Cai, C. Y.; Luo, Y. Y; He, Z. H.; J. Supercond. 2004, $17,383$.

26. Gans, P.; Sabatini, A.; Vacca, A.; Talanta 1996, 43, 1739.

27. Alderighi, L.; Gans, P.; Lenco, A.; Peters, D.; Sabatini, A.; Vacca A.; Coord. Chem. Rev. 1999, 184, 311.

28. Smith, R. M.; Martell, A. E.; Critical Stability Constants, vol. 3; Plenum Press: New York, 1977.

29. Martell, A. E.; Smith, R. M.; Critical Stability Constants, vol. 2; Plenum Press: New York, 1975.

30. Thuy, T. T.; Hoste, S.; Herman, G. G.; Van de Velde, N.; De Buysser, K.; Van Driessche, I.; J. Sol-Gel Sci. Technol. 2009, $51,112$.

31. Harris, D.C.; Quantitative Analytical Chemistry; W. H. Freeman: New York, 2006.

32. Rufus, A. L.; Sathyaseelan, V. S.; Srinivasan, M. P.; Kumar, P. S.; Veena, S. N.; Velmurugan, S.; Narasimhan, S. V.; Prog. Nucl. Energy 2001, 39, 285.
33. Howard, P. H.; Meylan, W. M; Funk, J.; Handbook of Physical Properties of Organic Chemicals; Boca Raton: Florida, 1995.

34. Mathur, S.; Shen, H.; Leleckaite, A.; Beganskiene, A.; Kareiva,A.; Mater. Res. Bull. 2005, 40, 439.

35. Schoofs, B.; Cloet, V.; Vermeir, P.; Schaubroeck, J.; Hoste, S.; Van Driessche, I.; Supercond. Sci. Technol. 2006, 19, 1178.

36. Kullberg, M. L.; Lanagan, M. T.; Wu, W.; Poeppel, R. B.; Supercond. Sci. Technol. 1991, 4, 337.

37. Kareiva, A.; Karppinen, M.; Niinisto, L.; J. Mater. Chem. 1994, 4, 1267.

38. Maneva, M, Nikolova, D.; J. Therm. Anal. 1998, 34, 637.

39. Moya, J. S.; Díaz, M.; Serna, C. J.; Mello-Castanho, S.; J. Eur. Ceram. Soc. 1998, 18, 1381.

40. Socrates, G.; Infrared and Raman Characteristic Group Frequencies: Tables and Charts; John Wiley \& Sons: Chichester, 2001.

Submitted: February 3, 2012

Published online: June 19, 2012 